\title{
Silk Protein-Based Membrane for Guided Bone Regeneration
}

\author{
Kwang-Jun Kwon ${ }^{1}$ and Hyun Seok ${ }^{2, *}$ \\ 1 Department of Oral and Maxillofacial Surgery, College of Dentistry, Gangneung-Wonju National University, \\ Gangneung 25457, Korea; jf1225@gwnu.ac.kr \\ 2 Department of Oral and Maxillofacial Surgery, Chungbuk National University Hospital, \\ Cheongju 28644, Korea \\ * Correspondence: sok8585@hanmail.net; Tel.: +82-43-269-6383
}

Received: 3 July 2018; Accepted: 20 July 2018; Published: 24 July 2018

\begin{abstract}
Silk derived from the silkworm is known for its excellent biological and mechanical properties. It has been used in various fields as a biomaterial, especially in bone tissue engineering scaffolding. Recently, silk protein-based biomaterial has been used as a barrier membrane scaffolding for guided bone regeneration (GBR). GBR promotes bone regeneration in bone defect areas using special barrier membranes. GBR membranes should have biocompatibility, biodegradability, cell occlusion, the mechanical properties of space-making, and easy clinical handling. Silk-based biomaterial has excellent biologic and mechanical properties that make it a good candidate to be used as GBR membranes. Recently, various forms of silk protein-based membranes have been introduced, demonstrating excellent bone regeneration ability, including osteogenic cell proliferation and osteogenic gene expression, and promoting new bone regeneration in vivo. In this article, we introduced the characteristics of silk protein as bone tissue engineering scaffolding and the recent application of such silk material as a GBR membrane. We also suggested future studies exploring additional uses of silk-based materials as GBR membranes.
\end{abstract}

Keywords: silk; fibroin; sericin; guided bone regeneration; barrier membrane; bone tissue engineering

\section{Introduction}

Guided bone regeneration (GBR) promotes new bone formation in bone defects using the barrier membrane [1]. The barrier membrane prevents the infiltration of the epithelial cells and the down growth of the connective tissue in the defect area [2]. It secures the space for the migration of osteoblasts and osteogenic cells and for new bone to grow in [2]. The barrier membrane must have several beneficial properties, such as biocompatibility, biodegradability without immune reaction, cell occlusion to prevent epithelial cell migration, the mechanical property for space making, tissue integration, and easy clinical handling [3]. However, there is no ideal barrier membrane that satisfies all of these properties. Generally, two types of the membrane have been used for GBR: resorbable and non-resorbable membranes [4].

Non-resorbable membranes, such as titanium mesh and titanium-reinforced expanded-polytetrafluoroethylene (e-PTFE), have high biocompatibility, mechanical properties, and stability [5]. They can stably maintain the form of grafted bone material and secure the space for bone growth [6]. The e-PTFE membrane effectively occludes the soft tissue cell invasion [7]. Even though non-resorbable membranes have had successful clinical outcomes in GBR, they can be more easily exposed in the oral cavity and lead to wound dehiscence compared with resorbable membranes [8], causing bacterial contamination on the membrane and potentially leading to the failure of the bone graft. Therefore, when membrane exposure occurs, it should be removed immediately [9]. Resorbable 
membranes have been widely used in clinical practice due to their advantages with similar results as the non-resorbable membranes [10]. As the main source of the resorbable membrane, collagen has good biocompatibility, low risk of membrane exposure and donor site infection, and no need of a secondary surgery for removal [11]. However, collagen membranes have weak mechanical properties, rapid biodegradation, and lower space-making ability compared to non-resorbable membranes [10]. To overcome this problem, cross-linking membranes have been manufactured, but the agent used in the cross-linking can be cytotoxic during degradation $[12,13]$.

Silk derived from the silkworm Bombyx mori (B. mori) is a natural biopolymer [14]. Silk is mainly composed of fibroin and sericin [14]. Silk fibroin (SF) has been used as a biomaterial after the removal of sericin by the degumming process [15]. Several types of SF material have been used for bone tissue engineering scaffolding, such as sponge, film, and hydrogel forms [16]. SF has excellent biocompatibility, biodegradation, oxygen and water permeability, and tissue integration [16]. Recently, the application of silk protein-based biomaterial for the GBR membrane has been reported $[17,18]$. SF membranes have good osteogenic cell adhesion and induce new bone formation [17]. Although SF has excellent biological benefits as GBR membranes, it has weak mechanical properties and is difficult to handle [19]. The silk mat from cocoons, which is not the result of the degumming process, shows excellent mechanical properties [20]. This silk mat can be separated in different layers by eco-friendly methods $[20,21]$. As a GBR membrane, it shows excellent tensile strength and comparable new bone regeneration in vivo [20,22].

The clinical indication of the GBR procedure has been increased in the maxillofacial bone region [23]. GBR membranes are applied to the areas of bone defect after cyst and tumor excision, tooth extraction, and deficient alveolar bone for implant installation [11,24]. However, commercially available GBR membranes have limitations according to their material, properties, and high prices [25]. The ideal GBR membrane has biological and mechanical properties, easy handling, and reasonable pricing [26]. Previously, various forms of silk protein-based membrane have been introduced for use in GBR [19]. Silk protein-based membranes have excellent osteogenic and mechanical properties and show potential as GBR membranes [17,21]. In this review, we investigated the characteristics of silk protein and introduced the recent study of the application of silk material as a GBR membrane. The bone regeneration ability of silk-based membranes was reviewed, and future studies are suggested for the use of silk membrane in the GBR technique.

\section{Silk Material Proteins}

Silk, as a protein polymer containing repetitive amino acids, is spun into fiber from the secretory gland of Lepidoptera larvae, such as silkworms, spiders, bees, and flies [27]. The composition and structure of silk differs depending on the species [28]. Silk derived from silkworms has been popularly used in the textile industry for centuries and in biomedical suture material for decades due to its excellent mechanical properties and biocompatibility [28]. Silk derived from silkworms consists of two major proteins, fibroin (72-81\%) and sericin (19-38\%) [14]. Both proteins contain the same 18 amino acids, including glycine, alanine, and serine in different ratios [14]. Fibroin composes the core of silk filament, and sericin coats the fibroin fiber (Figure 1). Sericin is a glue-like protein that makes two fibroin fibers bind together [29]. Sericin is a water-soluble protein, and generally, it is removed by the thermochemical treatment known as the degumming process [15]. Silk-based biomaterial has been used as a suture material for wound treatment, and recently, it has been widely used as the major component of biomaterials, including bone tissue scaffolding, wound dressing materials, drug delivery, and vascular patches $[27,30]$. Silk material has suitable properties for use as bone scaffolding material, and it can be easily obtained and processed in various forms of scaffolding [29]. 


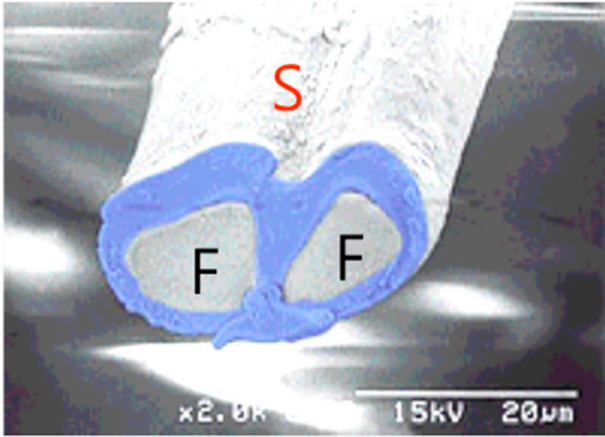

(a)

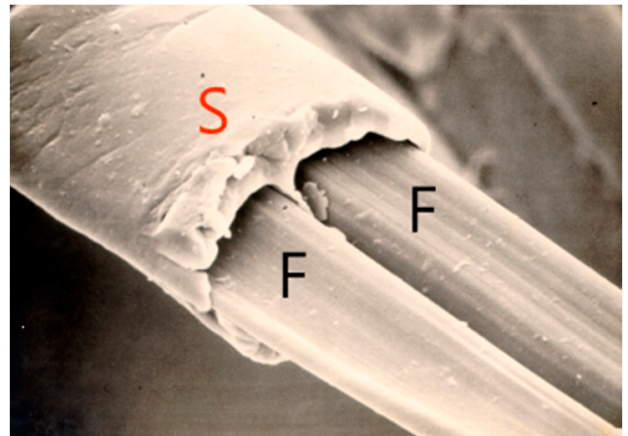

(b)

Figure 1. Scanning electron microscopic view of cocoon fiber. (a) The silk mat is composed of interconnecting strings. Each string has two main fibers (F) and surrounding bonding proteins (S). (b) After the removal of sericin (S), two fibers composed of silk fibroin (F) remain.

\subsection{Fibroin}

$\mathrm{SF}$ is hydrophobic protein and forms the core of silk filament [31]. It is approximately 10-25 $\mu$ in diameter and consists of two different proteins, which are heavy $(\mathrm{H})$ and light $(\mathrm{L})$ chain [32]. $\mathrm{H}$ and $\mathrm{L}$ chains connect with a single disulfide bond and have molecular weights of 325 and $25 \mathrm{kDa}$, respectively [33]. The P25 glycoprotein $(25 \mathrm{kDa})$ is linked to the $\mathrm{H}$ and $\mathrm{L}$ complex with a non-covalent bond [33]. The $\mathrm{H}$ and $\mathrm{L}$ chains and $\mathrm{P} 25$ appear in SF with a 6:6:1 ratio [32]. The amino acid sequence of the $\mathrm{H}$ chain contains the repetitive hexapeptide of Gly-Ala-Gly-Ala-Gly-Ser and dipeptide of Gly-Ala/Ser/Tyr, and it forms a more stable anti-parallel $\beta$-sheet crystallites structure [34]. While the $\mathrm{H}$ chain contains the repetitive peptide and is more hydrophobic, the $\mathrm{L}$ chain is non-repetitive and more hydrophilic [35]. The secondary structure of SF is the random coil and the anti-parallel $\beta$-sheet structure, which is connected to each peptide by a hydrogen bond [36]. The main crystal structure of SF is silk I and II. Silk I contains the random coil and amorphous structures, and silk II has an anti-parallel $\beta$-sheet structure with hydrogen bonds [35]. These strong hydrogen bonds with adjacent chains contributes to the mechanical and tensile strength of SF $[16,35,37]$.

$\mathrm{SF}$ is purified from sericin by the degumming process, which consists of boiling silk cocoons in alkaline solution [14]. It provides the mechanical properties of strength and toughness of silk fibers [14]. It also shows excellent biocompatibility, biodegradation, and differentiation of mesenchymal cells [33]. SF was recognized as a biomaterial by the United States (US) Food and Drug Administration (FDA) in 1993 [35]. SF has been used as a natural biopolymer for scaffolding for bone substitute materials [35]. Several types of SF materials have been manufactured for bone tissue engineering scaffolding, such as sponges, films, hydrogels, and membranes [16]. SF membranes are easily processed by casting or an electrospinning technique using a SF solution $[27,38]$. Degummed silk cocoons are dissolved in the solvent mixture [16], and the mixture is dialyzed and formed into the aqueous SF solution [16,27]. SF membranes are obtained by casting this solution on a specific dish or plate, and it is transparent, rapidly soluble, and brittle in its dry state [19]. Electrospinning nanofibers have been used for the manufacture of SF membranes [39]. These membranes show improved mechanical properties and slow degradability $[38,39]$. Both SF membranes show excellent osteogenic cell affinity and induce the new bone regeneration on the animal calvarial defect as a barrier membrane $[19,39,40]$.

\subsection{Sericin}

Sericin is a natural protein produced from the middle silk gland of the silkworm [41]. It coats the fibroin fiber and acts as an adhesive to hold two fibroin fibers together [41]. It is composed of 18 amino acids and serine, aspartic acid, and glycine in proportions of approximately $33.4 \%, 16.7 \%$, and $13.5 \%$, respectively $[42,43]$. Sericin is a hydrophilic protein mainly composed of an amorphous random coil 
structure and less $\beta$-sheet structure [44]. Sericin has been considered to be a by-product of the silk cocoon and discarded by the degumming process. However, a recent study has shown that sericin has favorable biologic properties and the potential to be used as a biomaterial component [45]. Sericin has biocompatibility, biodegradability, antibacterial activity, and resistance to oxidative stress and ultraviolet radiation $[46,47]$. The immunologic response is a major concern when considering using sericin as a biomaterial. However, sericin is known as a biocompatible polymer and induces a very weak immunologic response when used alone [48]. Sericin is now used in various fields, including pharmacologic, cosmetic, and biomedical applications [45].

Sericin has been suggested as a biomaterial for tissue regeneration [41]. Sericin is more hydrophilic than fibroin and can more effectively induce collagen synthesis in dermal tissue. It is a good candidate for use in tissue engineering scaffolding as a dressing material or skin substitute [49]. Sericin film increases the proliferation of human skin keratinocytes and fibroblasts, and it accelerates wound healing [49]. Sericin also has antimicrobial, antioxidant, and photo-protective ability from ultraviolet radiation, so it has been effectively used as a dressing material for skin protection [50,51]. Sericin shows potential as a bone tissue engineering scaffolding material. Hydroxyapatite (HA) and sericin composite improves cell viability and increases the differentiation of osteogenic cells [52,53], and sericin coating on a titanium implant induces the adhesion, differentiation, and proliferation of osteoblast cells on the implant's surface [54]. It may enhance osseointegration of titanium implants and bone healing. Silk cocoon membranes containing fibroin and sericin have been studied as GBR membranes [20]. Silk cocoons may be separated into different layers, and the composition of sericin gradually increases from the inner layer to the outer layer [20]. Low concentration and release of sericin from the middle layer of silk cocoons induce increased osteogenic gene expression and affect the new bone regeneration without immune reaction in vivo [20,55].

\section{Silk Fibroin Membrane}

\subsection{Silk Fibroin Only Membrane}

SF as natural biomaterial has been studied for use in the scaffolding of bone tissue engineering [35]. $\mathrm{SF}$ has been known as a biocompatible and biodegradable biomaterial [29]. However, SF is a high-molecule natural polymer and can induce an inflammatory reaction when implanted in the human body. Therefore, low molecular SF power is used as a bone graft scaffold [56]. Low molecular SF power shows favorable osteogenic cell properties in in vitro studies. It increases the expression of osteogenic genes, including alkaline phosphatase (ALP), collagen type 1, and transforming growth factor- $\beta 1$, and the ALP activity in MG-63 cells [56]. In vivo, the low molecular SF power combined with Choukroun platelet-rich fibrin showed rapid bone regeneration compared with the empty defect in a rabbit calvarial defect and a rabbit tibia peri-implant defect $[57,58]$.

SF can be manufactured as a membrane-type scaffold for use as a GBR membrane [59]. GBR membranes should have several properties, such as biocompatibility, mechanical properties for space maintenance, cell occlusion of connective tissue cells, and biodegradability without inflammatory reaction [10]. SF membranes can be made by an electrospinning and casting technique [27]. SF membrane has shown cell and tissue compatibility and the increase of osteogenic cell proliferation (Figure 2) [17]. The electrospinning SF nanofiber membrane increased osteoblast-like cell attachment and proliferation according to the culture period, and the expression of osteocalcin and ALP activity were increased [38]. SF nanofiber membrane in a rabbit calvarial defect showed significantly increased new bone regeneration compared with the empty defect without inflammatory reaction [38]. Compared with commercial collagen membranes, SF nanofiber membranes have shown satisfactory mechanical stability and new bone regeneration ability in a rat calvarial defect [39]. In clinical application, SF nanofiber membranes have shown similar bone regeneration ability compared with polylactic acid/poly(lactic/glycolic) acid (PLA/PLGA) membranes in tooth extraction defects [60,61]. 

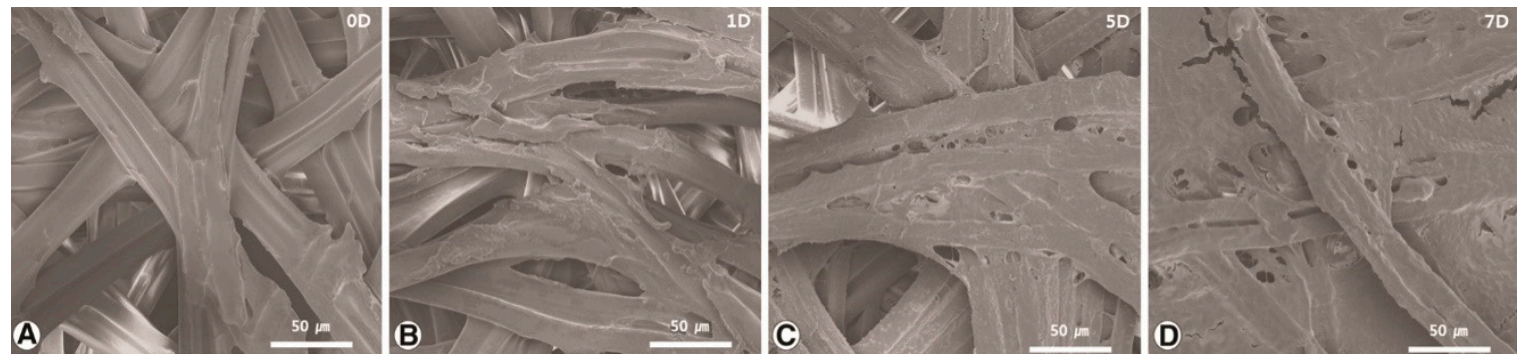

Figure 2. Scanning electron microscopy (SEM) images of cell attachment on the surface of silk fibroin (SF) membranes. (A) SEM image shows the SF membrane surface for day 0; (B) the cells gradually filled across the fiber texture, covering approximately $10-20 \%$ of the SF membrane surface; (C) at 5 days, the gap between the SF membrane fibers was filled and covered by the cell attachment; (D) at 7 days, the surface of the SF membrane was nearly filled and covered with cells (reproduced from previous publication by permission) [17].

The SF membrane manufactured by the casting technique showed higher new bone regeneration ability than the uncovered defect in a rabbit calvarial defect (Figure 3) [19], and compared with the collagen membrane, it shows comparable new bone regeneration without inflammatory reaction [40]. However, the casting SF membrane has weak mechanical properties and is brittle in its dry state [19]. Despite their low mechanical properties and difficult handling, SF membranes can be suitable barrier membranes for GBR due to their low cost and biocompatibility [40]. In the previously reported study, the silk-based membranes showed their potential as GBR membranes. They have favorable osteogenic cell compatibility and new bone regeneration ability with low immune reaction.

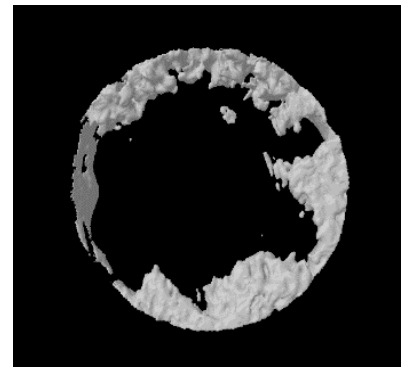

(a)

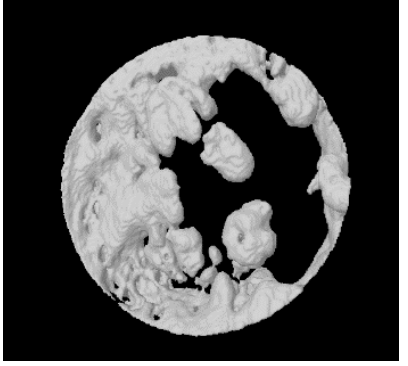

(b)

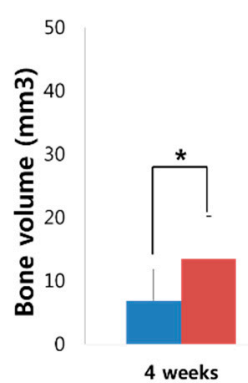

4 weeks

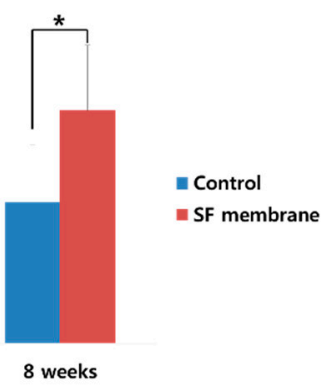

(c)

Figure 3. Micro-computerized tomography (CT) image at 8 weeks after operation [19]. SF membrane was applied on the rabbit calvarial defect. (a) Unfilled defect in the control group; (b) SF membrane group; (c) bone volume analysis of the micro-CT. New bone formation was significantly higher in the SF membrane group than the control $\left({ }^{*} p<0.05\right)$. (“*” means significant difference).

\subsection{Silk Fibroin Membrane with Other Components}

\subsubsection{4-Hexylresorcinol}

4-hexylresorcinol (4-HR) is natural phenolic compound that has antimicrobial, antioxidant, and antimutagenic activity [62]. It has been used as a food additive for preventing the enzymatic browning of fruit and seafood [63]. Medically, it has been used as an antiparasitic and antiseptic agent, and now, it is used as a topical antiseptic ingredient for skin and throat lozenges [64,65]. 4-HR has an anticancer effect through the suppression of the transglutaminase and inhibition of the nuclear factor- $\mathrm{KB}(\mathrm{NF}-\mathrm{\kappa B})$ pathways [66]. The NF- $\kappa B$ pathway is related to osteoclast differentiation, and the NF- $\kappa B$ pathway inhibitor can impair the osteoclast activation $[67,68]$. As a result, 4-HR can inhibit the osteoclast activation, and it may contribute to new bone regeneration. 
4-HR has been used as an ingredient of bone graft material, and it has shown favorable results in new bone regeneration [69]. The 4-HR and HA combined graft material has shown higher initial bone regeneration in a rabbit calvarial defect [70]. 4-HR is coated on the titanium alloy surface and induces the osteogenic cell proliferation and contributes to the osseointegration of the implant. The 4-HR and HA coating titanium surface shows more rapid cell proliferation and higher osteocalcin expression and ALP activity than the HA-only surface coating. The HA and 4-HR coating implant requires higher torque for removal and shows more bone contact area than the HA-only implant coating [71]. The antiseptic property and inhibition of osteoclastogenesis of 4-HR may contribute to the osteogenic marker expression and osseointegration of the implant.

4-HR is a component of silk-based membranes for the GBR technique, and it shows higher bone regeneration ability in bone defects [72]. 4-HR-incorporated silk membranes are used in the calvarial defect, and they show more new bone regeneration compared with silk-only membranes [73], and the 3\% 4-HR-loaded silk membrane showed more new bone formation compared with the commercial collagen membrane in the rabbit calvarial defect (Figure 4) [72,74]. In peri-implant defects, 4-HR stably maintains the space for new bone growth and effectively induces new bone regeneration around the implant (Figure 5) [18]. 4-HR has antiseptic and osteoclast inactivation activity and can be used as major component of the silk membrane for the GBR technique.

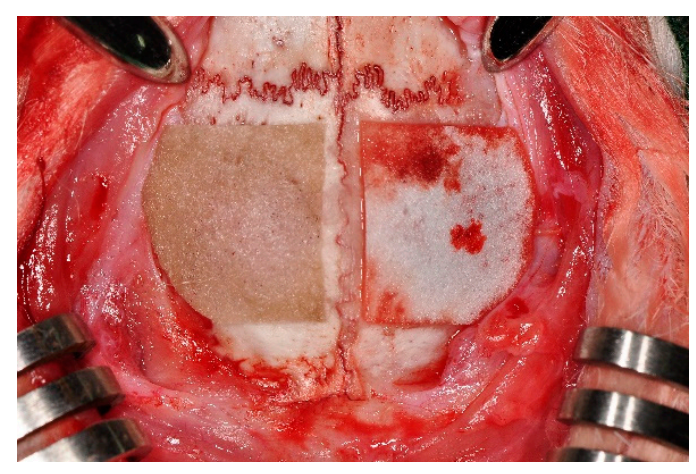

Figure 4. 3\% 4-hexylresorcinol (4-HR) + silk membrane (left side) or collagen membrane (right side) was applied on the parietal bone defect of a rabbit [72].

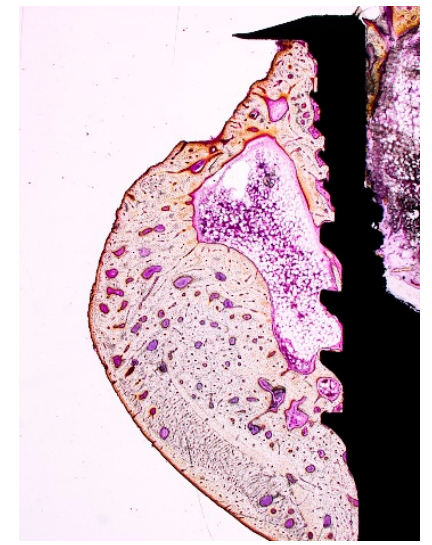

(a)

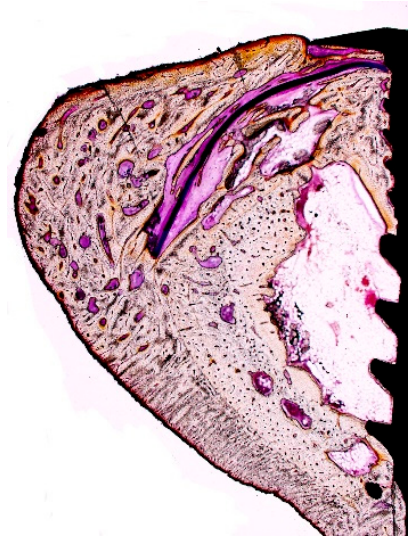

(b)

Figure 5. Silk fibroin +4 -HR membrane was applied in a peri-implant defect [18]. Histological images at 8 weeks after operation. (a) Unfilled peri-implant defect in the control group; (b) silk fibroin +4 -HR group shows new bone regeneration in the peri-implant defect. Residual membrane (black arrow).

Grafted biomaterial can induce the foreign body reaction and giant cell formation in the implanted site [75]. 4-HR inhibits the foreign body reaction through suppression of diacylglycerol kinase 
(DAGK) expression [76]. 4-HR decreases giant cell formation and phagocytosis in raw cells. Silk graft material treated with 4-HR shows increased biodegradation and bone formation with less foreign body reaction [76]. From a previous study, 4-HR shows antimicrobial activity and inhibits the foreign body reaction and osteoclast inactivation $[66,67]$. 4-HR can be stably incorporated with a silk membrane, so it can be effectively used as a component of the barrier membrane for preventing the foreign body reaction of the GBR membranes [18].

\subsubsection{Tetracycline}

Tetracycline (TC) is a broad-spectrum antibiotic that is effective against gram-positive and negative bacteria [77]. It inhibits the protein synthesis of bacteria and has bacteriostatic activity [77]. TC has an affinity to the mineralizing tissue of bone and tooth and causes the proliferation of osteoblastic cell [78]. It decreases the degradation of the collagen matrix and bone resorption and has been used for the treatment of periodontal disease $[79,80]$. Using its antimicrobial and therapeutic activity, TC has been used as a component of the SF membrane for new bone regeneration [81].

TC has different osteogenesis effects depending on the concentration [80]. In vitro, the $1 \%$ and $5 \%$ TC-loaded SF membranes showed more proliferation and osteogenic potential in a gingiva-derived mesenchymal cell compared with that of 10\% TC. The 1\%, 5\%, and 10\% TC-loaded SF membranes in a rat calvarial defect showed more bone formation compared with the SF-only membrane, and significantly higher bone formation was observed in the 5\% TC-loaded membrane (Figure 6 and Table 1) [81]. In another study, the 1\% TC-loaded SF membrane showed increased new bone formation compared with the SF-only membrane [82]. The antibiotic activity of TC helps to prevent bacterial infection, and the osteogenic property of TC leads to the increase of new bone formation in the defect area [82]. However, the TC-loaded SF membranes are brittle and weak in their dry states and are difficult to handle, such as in the casting of the SF membrane [82]. Weak mechanical properties should be improved for clinical use as GBR membranes. In high concentrations, TC can inhibit the proliferation of osteoblasts [83]. The optimal concentration should be established for the use of TC as a component of the GBR membrane.

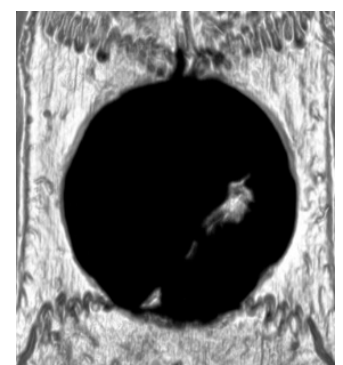

(a)

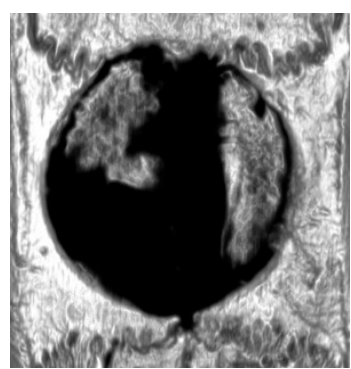

(b)

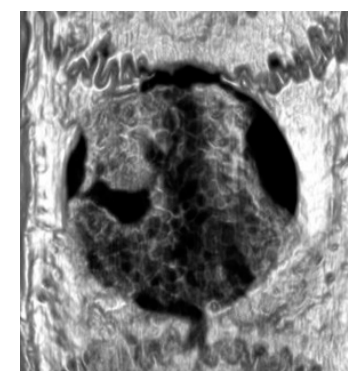

(c)

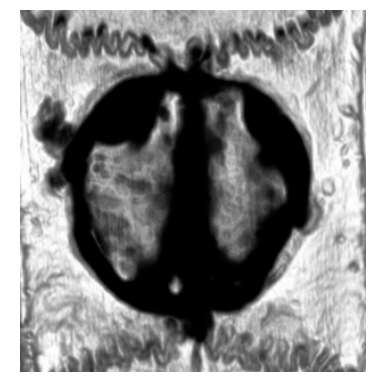

(d)

Figure 6. Micro-computed tomography at 4 weeks after operation. Tetracycline (TC)-loaded SF membrane was applied on a rabbit calvarial defect [81]. (a) SF membrane; (b) 1\% TC-loaded SF membrane; (c) 5\% TC-loaded SF membrane; (d) 10\% TC-loaded SF membrane.

Table 1. Micro-computed tomographic analysis.

\begin{tabular}{ccccc}
\hline Group & SFM & TC1 & TC5 & TC10 \\
\hline Bone volume $\left(\mathrm{mm}^{3}\right)$ & $2.00 \pm 1.81$ & $3.65 \pm 2.86$ & $9.87 \pm 3.80$ & $4.86 \pm 1.86$ \\
\hline
\end{tabular}

(SFM: Silk fibroin membrane, TC1: 1\% tetracycline-loaded SFM, TC5: 5\% tetracycline-loaded SFM, TC10: $10 \%$ tetracycline loaded-SFM). 


\subsubsection{Chitosan, Hydroxyapatite, and Growth Factors}

Chitosan is a natural polysaccharide derived from chitin that is known for its excellent biologic properties, including biodegradability, biocompatibility, and antimicrobial activity [84]. Chitosan has been used in biomedical and pharmaceutical applications, such as in wound healing, drug carriers, and tissue engineering scaffolding [85]. Chitosan is blended with SF and widely used in the tissue engineering scaffolding of bone and cartilage and skin healing [86]. Various forms of chitosan-blended SF scaffolds can be manufactured for bone tissue engineering, such as film, nanofiber, and membranes, and it shows good osteogenic properties by increasing osteogenic cell proliferation and gene expression $[84,87,88]$.

HA is blended with chitosan-SF membrane to strengthen its mechanical properties [87]. HA is the main inorganic component of natural bone and has biocompatible, biodegradable, and osteoconductive properties [89,90]. It provides higher mechanic strength and stability in the membrane [91]. Chitosan-fibroin-HA membranes have shown comparable new bone regeneration with commercial collagen membranes in a rat calvarial defect $[92,93]$. They have not shown any obvious inflammatory reaction, and they have the potential to be used as a GBR membrane [93].

Growth factors play an important role in bone tissue repair and remodeling [94,95]. Growth factors, such as bone morphogenetic protein (BMP) and vascular endothelial growth factor (VEGF), are combined with the chitosan-fibroin scaffold to promote bone regeneration $[96,97]$. Chitosan-fibroin-HA membranes have biocompatibility and mechanical properties, and BMP has osteoinductive activity [98]. BMP has been successfully incorporated in the core of chitosan-fibroin-HA nanofiber membranes, and these membranes have increased osteogenic cell differentiation and gene expression [96]. VEGF is a major regulator of angiogenesis and supports osteogenesis [99,100]. VEGF combined with a chitosan-SF scaffold has enhanced osteoblast cell proliferation and has shown its potential as a scaffold of bone tissue engineering [97]. BMP and VEGF provide osteogenic benefits to the scaffolding, and chitosan-fibroin is expected to be an ideal bone tissue engineering scaffold.

\section{Silk Mat as GBR Membrane}

Silkworm cocoons have a multi-layered structure (Figure 7), and the silk mat is produced from silkworm cocoons by cutting and peeling off [20]. As it is produced manually without any chemical treatment, its production is eco-friendly [20]. As the size of the cocoon is limited, the size of the silk mat is also limited. Because silkworm cocoons have a layered structure, their separation into thin membranes is easy. By manual separation, their thickness can be $0.01-0.2 \mathrm{~mm}$. This silk mat shows good tensile strength in wetting conditions [20,22]. Considering the oral environment, high tensile strength in wetting conditions is an advantage.

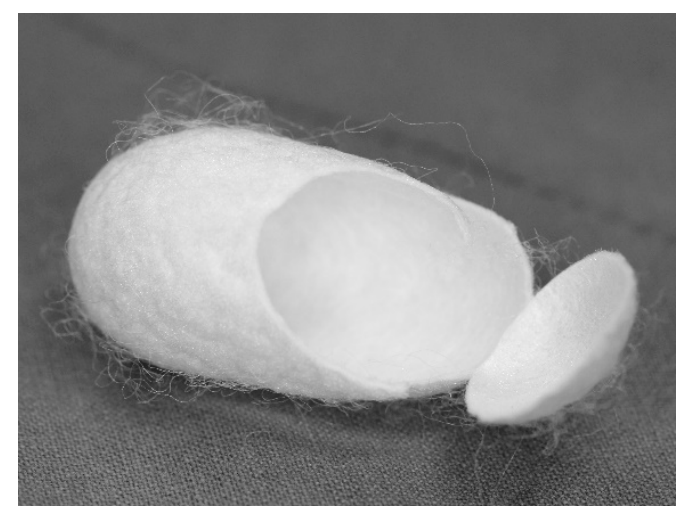

(a)

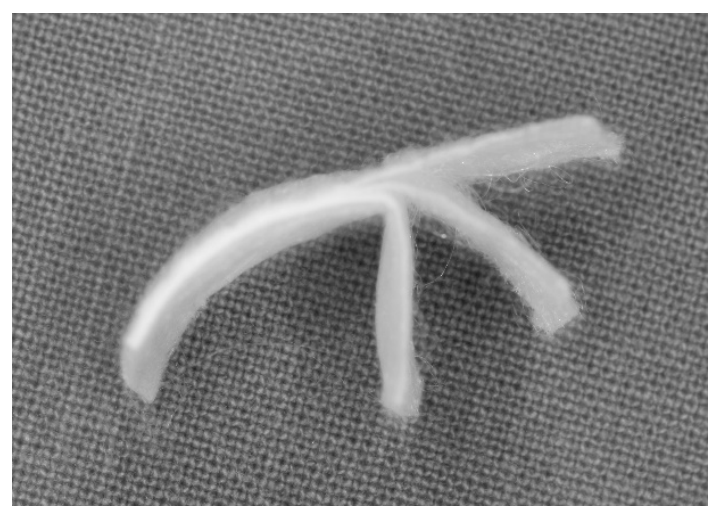

(b)

Figure 7. Silkworm cocoon. (a) After removing the larva, the cocoon has a Rugby ball-like structure; (b) when the cocoon is cut into a rectangular shape, it is easily peeled off as many sheets. 


\subsection{Composition of Silk Mat}

The composition of the silk mat is different from its origin in the cocoon. The composition of silk fibroin is almost consistent from the innermost to the outermost layers of the silkworm cocoon [101]. Silk sericin is considered as a bonding protein among hydrophilic silk fibers. The content of silk sericin is different from the innermost layer to the outermost layer. The amount of sericin in the silk mat increases from the inner to outer layers [102]. The sericin in the innermost layer is more or less 15\%, and in the outermost layer, it is $25 \%$ [102]. Seroin is considered to be an anti-septic protein, and its content decreases from the inner to the outer layers [101]. The amount of various protease inhibitors is also different according to the layer [103]. However, the detailed biological significance of each cocoon protein has been largely unknown. The removal of the bonding proteins is called degumming $[45,47]$. The product of degumming is mostly sericin, but it is basically a heat-denatured protein. The natural state has rarely been studied.

\subsection{Physical Properties of Silk Mat}

The silk mat has shown better physical properties compared with collagen or e-PTFE membranes [22]. The tensile strength of the silk mat in the middle layer is $27.6 \mathrm{MPa}$, but those of collagen membranes and e-PTFE are 3.5 MPa and 4.3 MPa, respectively [22]. Pore and fiber size is increased from the inner layer to the outer layer (Figure 8).

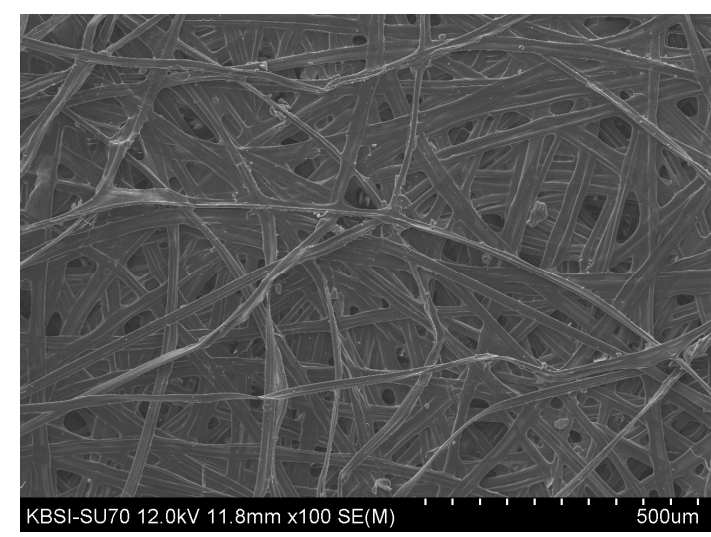

(a)

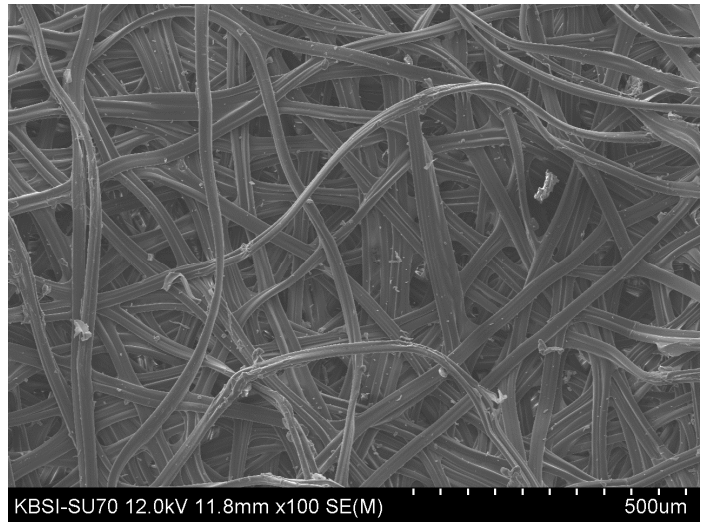

(b)

Figure 8. Scanning electron microscopic view of a silkworm cocoon. (a) The silk mat from the innermost layer. The dense fibrotic network is shown with a small pore size; (b) the silk mat from the outermost layer. The pore size and fiber thickness are larger than those in the innermost layer.

The silk mat from the middle layer and outer layer shows more water compatibility compared with that from the inner layer (Figure 9). 
Inner

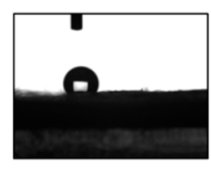

$10 \mathrm{~min}$

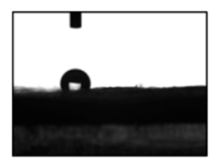

$20 \mathrm{~min}$

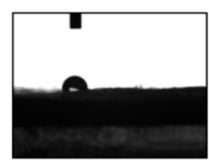

$25 \min$
Middle
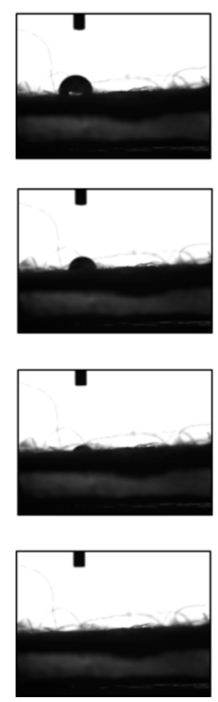

Outer
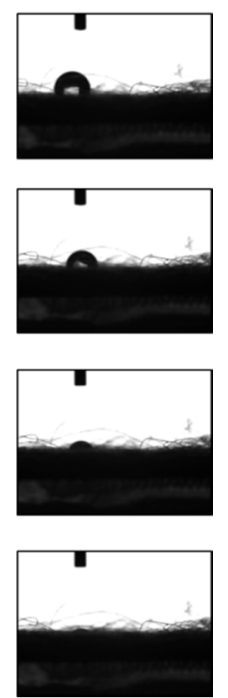

Figure 9. Water drop experiment. As sericin content is increased from the inner to outer layers and sericin is a hydrophilic protein, water drops are adsorbed quickly in the middle and the outer layer groups.

\subsection{In Vitro Properties of Silk Mat}

SF has been considered a cyto-compatible material [10]. Recently, sericin has been widely studied as a biomaterial, and most results seem to be promising [48,54]. However, most papers studied sericin as a degumming by-product [45,47]. Accordingly, they denatured sericin by boiling. Silk mat is mostly composed of silk fibroin and sericin [20]. As SF is hydrophobic and surrounded by bonding proteins, the fibroin effect on cellular culture is minimal in the silk mat. Natural sericin is fragmented in an aqueous solution and solubilized in water. The fragmented natural sericin is a biologically important component in the silk mat when it is used as a biomaterial [55]. The silk mat also has abundant protease inhibitors, which are released from the silk mat [103].

When degumming products are given to RAW264.7 cells, TNF- $\alpha$ (tumor necrosis factor- $\alpha$ ) is increased in a dose-dependent manner [55]. As TNF- $\alpha$ is important in acute and chronic inflammation, degumming products should be used in a controlled manner. In the case of the silk mat, natural sericin will be released in a fragmented form. In addition, the content of sericin is different from the layers of the cocoon [101]. Considering dose-dependent TNF- $\alpha$ induction by denatured sericin [55], the sericin content in the silk mat should be small. As the content of sericin is increased from the inner to the outer layers, the silk mat from the inner layer may be better than that from the outer layer. There are other bonding proteins to sericin, such as seroin and protease inhibitors [101]. Although few studies have been conducted on these proteins, they may induce TNF- $\alpha$-like sericin. In the case of seroin, it is abundant in the inner layer [101]. When TNF- $\alpha$ induction experiments are done for the silk mat leaching solution, the least TNF- $\alpha$-induced silk mat comes from the middle layer of the silkworm cocoon [55].

Silk sericin has been used as dressing materials and cosmetics [45,47]. Implants coated with silk sericin show better bone formation than those without [54]. Accordingly, silk sericin may be beneficial for wound healing and bone regeneration [48,54]. However, detailed characterization of silk sericin in previous studies has been largely unclear. Most studies categorize silk sericin as a whole silk industrial by-product from the degumming process; however, it may be different from silk sericin protein. In detail, silk sericin itself would also vary from species to species in silkworms. These differences may cause difficulty in reproducing the results of previous papers. The silk mat from the middle layer of 
B. mori has been used for a toxicological survey by the Korea Food and Drug Administration (KFDA), and permission to export was received. B. mori cannot eat any contaminated mulberry leaves [104]. Chemically contaminated leaves are toxic for B. mori [104]. No micro-organism has been identified that can infect both human and B. mori [104]. In addition, infected larva cannot form cocoons [104]. Collectively, the silk mat from silkworm cocoons is a highly safe source of biomaterials compared with any materials from mammals.

\subsection{Animal Experiment and Clinical Trials}

Cellular experiments have indicated that the silk mat from the middle layer of the cocoon has an advantage to the others, and this hypothesis has been studied in an animal model. The silk mat from the middle layer was compared to collagen and e-PTFE membranes in a rat calvarial defect model [22]. The silk mat showed bone regeneration similar to collagen and superior to e-PTFE membranes [22]. When the whole layer of cocoon was used for the GBR membrane, its bone formation ability was inferior to the silk mat from the middle layer [21]. If silkworm cocoons are separated into four silk mats of even thickness, the middle two groups showed better bone formation than the innermost and outermost groups [55].

Based on cellular and animal model results, the KFDA approved clinical trials for silk mat as a GBR technique (SPENSER-TS101, approved on 27 November 2015, Figure 10). These clinical trials were also approved by the institutional review board of Hallym Medical Center (2016-S016). A total of 25 patients having bilaterally impacted third molars were enrolled. Patients received e-PTFE membranes and silk mat membranes after tooth removal, and the application side was selected randomly. A single patient received both type of membranes, the comparison between membrane groups was done by paired samples t-test. When bone regeneration was evaluated at 6 months after the operation, there was no significant difference between the groups (Figure 10; $p>0.05$ ). In addition, both groups showed significant bone gain when compared immediately after the extraction and 6 months after the extraction $(p<0.05)$. The amount of bone gain was approximately $4 \mathrm{~mm}$. When the bone defect after the removal of a deeply impacted mandibular third molar was allowed to heal naturally, the amount of bone gain was approximately $2 \mathrm{~mm}$. The differences between application groups were also statistically significant $(p<0.05)$. There were no serious complications in the silk mat application. When the silk mat was exposed to an oral cavity by wound dehiscence, it could be contaminated by foods and cause inflammation, similar to other types of membranes. However, wound dehiscence was surgical-technique sensitive and not caused by the material.

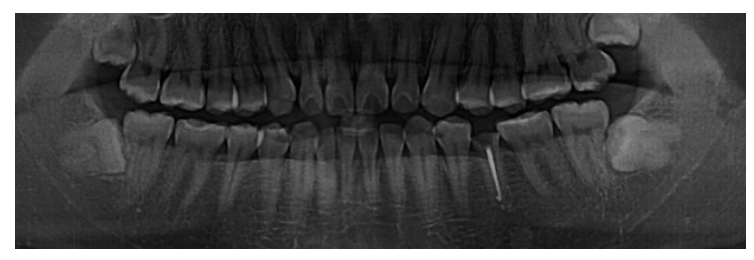

(a)

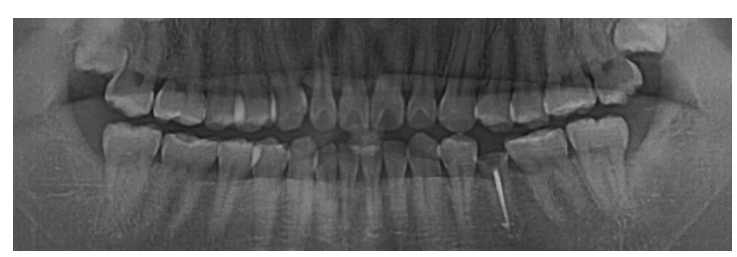

(b)

Figure 10. Clinical trials for silk mat. (a) Before extraction of bilaterally impacted mandibular third molars. Silk mat was applied to the right, and titanium-reinforced expanded-polytetrafluoroethylene (e-PTFE) was applied to the left by random assignment; (b) six months after extraction. Both wounds were healed without any event.

\section{Conclusions}

Silk derived from silkworms as a biomaterial has been used in various forms of bone tissue engineering scaffolding. Silk has excellent biological and mechanical properties as a GBR membrane. SF obtained from the degumming process has been manufactured as a barrier membrane. SF membrane shows excellent osteogenic cell differentiation and proliferation and new bone regeneration ability. 
The SF membrane is stably incorporated with antimicrobial agents, biomaterials, and growth factors, and it shows the synergistic effect of new bone regeneration. Although SF membranes have weak mechanical properties and difficult clinical handling, they show a potential as a GBR membrane. Silk mat has excellent mechanical strength and stability. It can be easily separated into different layers from the cocoon. The middle layer of the silk mat shows more strength and new bone regeneration ability compared with a commercial membrane. The middle layer shows less immunological reaction compared with the outer and inner layers and shows a great potential as a GBR membrane in clinical trials. Various forms and combinations of silk-based membranes have been developed. Although it shows excellent potential as a GBR membrane, more biocompatible and biodegradable silk-based membrane scaffolding should be developed that is free from the foreign body reaction. The improvement of clinical handling and incorporation with other biomaterials, growth factors, and medial agents were discussed for further development. Further study is needed for the clinical use of silk-based membrane in the GBR technique.

Author Contributions: K.-J.K. conceived of and designed the study; and K.-J.K. and H.S. wrote the first draft and reviewed and edited the paper. All of the authors read and approved the final version of the manuscript.

Funding: This research received no external funding.

Acknowledgments: This work was carried out with the support of the Cooperative Research Program for Agriculture Science and Technology Development (Project No. PJ01313902), Rural Development Administration, Republic of Korea.

Conflicts of Interest: The authors declare no conflict of interest.

\section{References}

1. Bottino, M.C.; Thomas, V.; Schmidt, G.; Vohra, Y.K.; Chu, T.M.G.; Kowolik, M.J.; Janowski, G.M. Recent advances in the development of GTR/GBR membranes for periodontal regeneration-A materials perspective. Dent. Mater. 2012, 28, 703-721. [CrossRef] [PubMed]

2. Dahlin, C.; Linde, A.; Gottlow, J.; Nyman, S. Healing of bone defects by guided tissue regeneration. Plast. Reconstr. Surg. 1988, 81, 672-676. [CrossRef] [PubMed]

3. McAllister, B.S.; Haghighat, K. Bone augmentation techniques. J. Periodontol. 2007, 78, 377-396. [CrossRef] [PubMed]

4. Jung, R.E.; Fenner, N.; Hämmerle, C.H.; Zitzmann, N.U. Long-term outcome of implants placed with guided bone regeneration (GBR) using resorbable and non-resorbable membranes after 12-14 years. Clin. Oral Implants Res. 2013, 24, 1065-1073. [CrossRef] [PubMed]

5. Lorenzoni, M.; Pertl, C.; Polansky, R.A.; Jakse, N.; Wegscheider, W.A. Evaluation of implants placed with barrier membranes. Clin. Oral Implants Res. 2002, 13, 274-280. [CrossRef] [PubMed]

6. Jovanovic, S.A.; Schenk, R.K.; Orsini, M.; Kenney, E.B. Supracrestal bone formation around dental implants: An experimental dog study. Int. J. Oral Maxillofac. Implants 1995, 10, 23-31. [PubMed]

7. Ronda, M.; Rebaudi, A.; Torelli, L.; Stacchi, C. Expanded vs. Dense polytetrafluoroethylene membranes in vertical ridge augmentation around dental implants: A prospective randomized controlled clinical trial. Clin. Oral Implants Res. 2014, 25, 859-866. [CrossRef] [PubMed]

8. Zitzmann, N.U.; Naef, R.; Schärer, P. Resorbable versus nonresorbable membranes in combination with Bio-oss for guided bone regeneration. Int. J. Oral Maxillofac. Implants 1997, 12, 844-852. [PubMed]

9. Verardi, S.; Simion, M. Management of the exposure of e-PTFE membranes in guided bone regeneration. Pract. Proced. Aesthet. Dent. 2007, 19, 111-117. [PubMed]

10. Lee, S.W.; Kim, S.G. Membranes for the guided bone regeneration. Maxillofac. Plast. Reconstr. Surg. 2014, 36, 239-246. [CrossRef] [PubMed]

11. Kim, S.Y.; Kim, Y.K.; Kim, H.S.; Yun, P.Y.; Kim, S.G.; Choi, Y.H. Extraction socket sealing using palatal gingival grafts and resorbable collagen membranes. Maxillofac. Plast. Reconstr. Surg. 2017, 39, 39. [CrossRef] [PubMed]

12. Bunyaratavej, P.; Wang, H.L. Collagen membranes: A review. J. Periodontol. 2001, 72, 215-229. [CrossRef] [PubMed] 
13. Speer, D.P.; Chvapil, M.; Eskelson, C.; Ulreich, J. Biological effects of residual glutaraldehyde in glutaraldehyde-tanned collagen biomaterials. J. Biomed. Mater. Res. 1980, 14, 753-764. [CrossRef] [PubMed]

14. Cao, Y.; Wang, B. Biodegradation of silk biomaterials. Int. J. Mol. Sci. 2009, 10, 1514-1524. [CrossRef] [PubMed]

15. Khan, M.M.R.; Tsukada, M.; Gotoh, Y.; Morikawa, H.; Freddi, G.; Shiozaki, H. Physical properties and dyeability of silk fibers degummed with citric acid. Bioresour. Technol. 2010, 101, 8439-8445. [CrossRef] [PubMed]

16. Vepari, C.; Kaplan, D.L. Silk as a biomaterial. Prog. Polym. Sci. 2007, 32, 991-1007. [CrossRef] [PubMed]

17. Yoo, C.K.; Jeon, J.Y.; Kim, Y.J.; Kim, S.G.; Hwang, K.G. Cell attachment and proliferation of osteoblast-like mg63 cells on silk fibroin membrane for guided bone regeneration. Maxillofac. Plast. Reconstr. Surg. 2016, 38, 17. [CrossRef] [PubMed]

18. Lee, S.W.; Kim, S.G.; Song, J.Y.; Kweon, H.; Jo, Y.Y.; Lee, K.G.; Kang, S.W.; Yang, B.E. Silk fibroin and 4-hexylresorcinol incorporation membrane for guided bone regeneration. J. Craniofac. Surg. 2013, 24, 1927-1930. [CrossRef] [PubMed]

19. Song, J.Y.; Kim, S.G.; Lee, J.W.; Chae, W.S.; Kweon, H.; Jo, Y.Y.; Lee, K.G.; Lee, Y.C.; Choi, J.Y.; Kim, J.Y. Accelerated healing with the use of a silk fibroin membrane for the guided bone regeneration technique. Oral Surg. Oral Med. Oral Pathol. Oral Radiol. 2011, 112, e26-e33. [CrossRef] [PubMed]

20. Kweon, H.; Jo, Y.Y.; Seok, H.; Kim, S.G.; Chae, W.S.; Sapru, S.; Kundu, S.C.; Kim, D.W.; Park, N.R.; Che, X. In vivo bone regeneration ability of different layers of natural silk cocoon processed using an eco-friendly method. Macromol. Res. 2017, 25, 806-816. [CrossRef]

21. Kim, S.G.; Kim, M.K.; Kweon, H.; Jo, Y.Y.; Lee, K.G.; Lee, J.K. Comparison of unprocessed silk cocoon and silk cocoon middle layer membranes for guided bone regeneration. Maxillofac. Plast. Reconstr. Surg. 2016, 38, 11. [CrossRef] [PubMed]

22. Ha, Y.Y.; Park, Y.W.; Kweon, H.; Jo, Y.Y.; Kim, S.G. Comparison of the physical properties and in vivo bioactivities of silkworm-cocoon-derived silk membrane, collagen membrane, and polytetrafluoroethylene membrane for guided bone regeneration. Macromol. Res. 2014, 22, 1018-1023. [CrossRef]

23. Oh, J.H. Recent advances in dental implants. Maxillofac. Plast. Reconstr. Surg. 2017, 39, 33. [CrossRef]

24. Cha, H.S.; Kim, J.W.; Hwang, J.H.; Ahn, K.M. Frequency of bone graft in implant surgery. Maxillofac. Plast. Reconstr. Surg. 2016, 38, 19. [CrossRef] [PubMed]

25. Rakhmatia, Y.D.; Ayukawa, Y.; Furuhashi, A.; Koyano, K. Current barrier membranes: Titanium mesh and other membranes for guided bone regeneration in dental applications. J. Prosthodont. Res. 2013, 57, 3-14. [CrossRef] [PubMed]

26. Caballé-Serrano, J.; Munar-Frau, A.; Ortiz-Puigpelat, O.; Soto-Penaloza, D.; Peñarrocha, M.; Hernández-Alfaro, F. On the search of the ideal barrier membrane for guided bone regeneration. J. Clin. Exp. Dent. 2018, 10, e477-e483. [CrossRef] [PubMed]

27. Qi, Y.; Wang, H.; Wei, K.; Yang, Y.; Zheng, R.Y.; Kim, I.S.; Zhang, K.Q. A review of structure construction of silk fibroin biomaterials from single structures to multi-level structures. Int. J. Mol. Sci. 2017, 18, 237. [CrossRef] [PubMed]

28. Aigner, T.B.; DeSimone, E.; Scheibel, T. Biomedical applications of recombinant silk-based materials. Adv. Mater. 2018, 30, 1704636. [CrossRef] [PubMed]

29. Altman, G.H.; Diaz, F.; Jakuba, C.; Calabro, T.; Horan, R.L.; Chen, J.; Lu, H.; Richmond, J.; Kaplan, D.L. Silk-based biomaterials. Biomaterials 2003, 24, 401-416. [CrossRef]

30. Crivelli, B.; Perteghella, S.; Bari, E.; Sorrenti, M.; Tripodo, G.; Chlapanidas, T.; Torre, M.L. Silk nanoparticles: From inert supports to bioactive natural carriers for drug delivery. Soft Matter 2018, 14, 546-557. [CrossRef] [PubMed]

31. Pérez-Rigueiro, J.; Elices, M.; Llorca, J.; Viney, C. Tensile properties of silkworm silk obtained by forced silking. J. Appl. Polym. Sci. 2001, 82, 1928-1935. [CrossRef]

32. Zhou, C.-Z.; Confalonieri, F.; Medina, N.; Zivanovic, Y.; Esnault, C.; Yang, T.; Jacquet, M.; Janin, J.; Duguet, M.; Perasso, R. Fine organization of bombyx mori fibroin heavy chain gene. Nucleic Acids Res. 2000, 28, 2413-2419. [CrossRef] [PubMed]

33. Inoue, S.; Tanaka, K.; Arisaka, F.; Kimura, S.; Ohtomo, K.; Mizuno, S. Silk fibroin of bombyx mori is secreted, assembling a high molecular mass elementary unit consisting of H-chain, L-chain, and p25, with a 6:6:1 molar ratio. J. Biol. Chem. 2000, 275, 40517-40528. [CrossRef] [PubMed] 
34. Zhou, C.Z.; Confalonieri, F.; Jacquet, M.; Perasso, R.; Li, Z.G.; Janin, J. Silk fibroin: Structural implications of a remarkable amino acid sequence. Proteins 2001, 44, 119-122. [CrossRef] [PubMed]

35. Melke, J.; Midha, S.; Ghosh, S.; Ito, K.; Hofmann, S. Silk fibroin as biomaterial for bone tissue engineering. Acta Biomater. 2016, 31, 1-16. [CrossRef] [PubMed]

36. Tsuboi, Y.; Ikejiri, T.; Shiga, S.; Yamada, K.; Itaya, A. Light can transform the secondary structure of silk protein. Appl. Phys. A 2001, 73, 637-640. [CrossRef]

37. Volkov, V.; Ferreira, A.V.; Cavaco-Paulo, A. On the routines of wild-type silk fibroin processing toward silk-inspired materials: A review. Macromol. Mater. Eng. 2015, 300, 1199-1216. [CrossRef]

38. Kim, K.H.; Jeong, L.; Park, H.N.; Shin, S.Y.; Park, W.H.; Lee, S.C.; Kim, T.I.; Park, Y.J.; Seol, Y.J.; Lee, Y.M. Biological efficacy of silk fibroin nanofiber membranes for guided bone regeneration. J. Biotechnol. 2005, 120, 327-339. [CrossRef] [PubMed]

39. Lu, S.; Wang, P.; Zhang, F.; Zhou, X.; Zuo, B.; You, X.; Gao, Y.; Liu, H.; Tang, H. A novel silk fibroin nanofibrous membrane for guided bone regeneration: A study in rat calvarial defects. Am. J. Transl. Res. 2015, 7, 2244-2253. [PubMed]

40. Kim, J.Y.; Yang, B.E.; Ahn, J.H.; Park, S.O.; Shim, H.W. Comparable efficacy of silk fibroin with the collagen membranes for guided bone regeneration in rat calvarial defects. J. Adv. Prosthodont. 2014, 6, 539-546. [CrossRef] [PubMed]

41. Lamboni, L.; Gauthier, M.; Yang, G.; Wang, Q. Silk sericin: A versatile material for tissue engineering and drug delivery. Biotechnol. Adv. 2015, 33, 1855-1867. [CrossRef] [PubMed]

42. Padamwar, M.; Pawar, A. Silk sericin and its applications: A review. J. Sci. Ind. Res. 2004, 63, 323-329.

43. Zhang, Y.Q. Applications of natural silk protein sericin in biomaterials. Biotechnol. Adv. 2002, 20, 91-100. [CrossRef]

44. Voegeli, R. Sericin silk protein: Unique structure and properties. Cosmet. Toilet. 1993, 108, 101-108.

45. Aramwit, P.; Siritientong, T.; Srichana, T. Potential applications of silk sericin, a natural protein from textile industry by-products. Waste Manag. Res. 2012, 30, 217-224. [CrossRef] [PubMed]

46. Zhaorigetu, S.; Sasaki, M.; Kato, N. Consumption of sericin suppresses colon oxidative stress and aberrant crypt foci in 1, 2-dimethylhydrazine-treated rats by colon undigested sericin. J. Nutr. Sci. Vitaminol. 2007, 53, 297-300. [CrossRef] [PubMed]

47. Kundu, S.C.; Dash, B.C.; Dash, R.; Kaplan, D.L. Natural protective glue protein, sericin bioengineered by silkworms: Potential for biomedical and biotechnological applications. Prog. Polym. Sci. 2008, 33, 998-1012. [CrossRef]

48. Aramwit, P.; Kanokpanont, S.; Punyarit, P.; Srichana, T. Effectiveness of inflammatory cytokines induced by sericin compared to sericin in combination with silver sulfadiazine cream on wound healing. Wounds 2009, 21, 198-206. [PubMed]

49. Siritientong, T.; Angspatt, A.; Ratanavaraporn, J.; Aramwit, P. Clinical potential of a silk sericin-releasing bioactive wound dressing for the treatment of split-thickness skin graft donor sites. Pharm. Res. 2014, 31, 104-116. [CrossRef] [PubMed]

50. Dash, R.; Acharya, C.; Bindu, P.; Kundu, S. Antioxidant potential of silk protein sericin against hydrogen peroxide-induced oxidative stress in skin fibroblasts. BMB Rep. 2008, 41, 236-241. [CrossRef] [PubMed]

51. Kaur, J.; Rajkhowa, R.; Tsuzuki, T.; Millington, K.; Zhang, J.; Wang, X. Photoprotection by silk cocoons. Biomacromolecules 2013, 14, 3660-3667. [CrossRef] [PubMed]

52. Zhang, H.; Wang, X.; Min, S.; Mandal, M.; Yang, M.; Zhu, L. Hydroxyapatite/sericin composite film prepared through mineralization of flexible ethanol-treated sericin film with simulated body fluids. Ceram. Int. 2014, 40, 985-991. [CrossRef]

53. Yang, M.; Shuai, Y.; Zhang, C.; Chen, Y.; Zhu, L.; Mao, C.; OuYang, H. Biomimetic nucleation of hydroxyapatite crystals mediated by antheraea pernyi silk sericin promotes osteogenic differentiation of human bone marrow derived mesenchymal stem cells. Biomacromolecules 2014, 15, 1185-1193. [CrossRef] [PubMed]

54. Nayak, S.; Dey, T.; Naskar, D.; Kundu, S.C. The promotion of osseointegration of titanium surfaces by coating with silk protein sericin. Biomaterials 2013, 34, 2855-2864. [CrossRef] [PubMed]

55. Jo, Y.Y.; Kweon, H.; Kim, D.W.; Baek, K.; Kim, M.K.; Kim, S.G.; Chae, W.S.; Choi, J.Y.; Rotaru, H. Bone regeneration is associated with the concentration of tumour necrosis factor- $\alpha$ induced by sericin released from a silk mat. Sci. Rep. 2017, 7, 15589. [CrossRef] [PubMed] 
56. Kim, J.Y.; Choi, J.Y.; Jeong, J.H.; Jang, E.S.; Kim, A.S.; Kim, S.G.; Kweon, H.Y.; Jo, Y.Y.; Yeo, J.H. Low molecular weight silk fibroin increases alkaline phosphatase and type I collagen expression in mg63 cells. BMB Rep. 2010, 43, 52-56. [CrossRef] [PubMed]

57. Lee, E.H.; Kim, J.Y.; Kweon, H.Y.; Jo, Y.Y.; Min, S.K.; Park, Y.W.; Choi, J.Y.; Kim, S.G. A combination graft of low-molecular-weight silk fibroin with choukroun platelet-rich fibrin for rabbit calvarial defect. Oral Surg. Oral Med. Oral Pathol. Oral Radiol. 2010, 109, e33-e38. [CrossRef] [PubMed]

58. Jang, E.S.; Park, J.W.; Kweon, H.; Lee, K.G.; Kang, S.W.; Baek, D.H.; Choi, J.Y.; Kim, S.G. Restoration of peri-implant defects in immediate implant installations by choukroun platelet-rich fibrin and silk fibroin powder combination graft. Oral Surg. Oral Med. Oral Pathol. Oral Radiol. 2010, 109, 831-836. [CrossRef] [PubMed]

59. Smeets, R.; Knabe, C.; Kolk, A.; Rheinnecker, M.; Gröbe, A.; Heiland, M.; Zehbe, R.; Sachse, M.; Große-Siestrup, C.; Wöltje, M. Novel silk protein barrier membranes for guided bone regeneration. J. Biomed. Mater. Res. B 2017, 105, 2603-2611. [CrossRef] [PubMed]

60. Hwang, W.J.; Jeong, S.N.; Kim, Y.S.; Pi, S.H.; You, H.K.; Chung, C.P.; Shin, H.S. Clinical study of guided bone regeneration of extracted socket with PLA/PGA membrane and silk fibroin membrane. J. Korean Acad. Periodontol. 2009, 39, 129-138. [CrossRef]

61. Han, D.H.; Hong, K.S.; Chung, C.H.; Yim, S.B. A comparative study for guided bone regeneration of silk fibroin nanomembrane (nanogide-s ${ }^{\mathrm{TM}}$ ). J. Korean Acad. Periodontol. 2008, 38, 475-482. [CrossRef]

62. Kozubek, A.; Tyman, J.H. Resorcinolic lipids, the natural non-isoprenoid phenolic amphiphiles and their biological activity. Chem. Rev. 1999, 99, 1-26. [CrossRef] [PubMed]

63. İyidoğan, N.; Bayındırlı, A. Effect of L-cysteine, kojic acid and 4-hexylresorcinol combination on inhibition of enzymatic browning in Amasya apple juice. J. Food Eng. 2004, 62, 299-304. [CrossRef]

64. Program, N.T. NTP toxicology and carcinogenesis studies of 4-hexylresorcinol (CAS No. 136-77-6) in F344/N Rats and B6C3F1 mice (Gavage Studies). Natl. Toxicol. Program Tech. Rep. Ser. 1988, 330, 1-166.

65. Rabbani, G.; Gilman, R.; Kabir, I.; Mondel, G. The treatment of fasciolopsis buski infection in children: A comparison of thiabendazole, mebendazole, levamisole, pyrantel pamoate, hexylresorcinol and tetrachloroethylene. Trans. R. Soc. Trop. Med. Hyg. 1985, 79, 513-515. [CrossRef]

66. Kim, S.G.; JeonG, J.H.; Park, Y.W.; SonG, J.Y.; Kim, A.S.; CHoI, J.Y.; Chae, W.S. 4-hexylresorcinol inhibits transglutaminase-2 activity and has synergistic effects along with cisplatin in KB cells. Oncol. Rep. 2011, 25, 1597-1602. [CrossRef] [PubMed]

67. Nakagawa, N.; Kinosaki, M.; Yamaguchi, K.; Shima, N.; Yasuda, H.; Yano, K.; Morinaga, T.; Higashio, K. Rank is the essential signaling receptor for osteoclast differentiation factor in osteoclastogenesis. Biochem. Biophys. Res. Commun. 1998, 253, 395-400. [CrossRef] [PubMed]

68. Castellano, D.; Sepulveda, J.M.; García-Escobar, I.; Rodriguez-Antolín, A.; Sundlöv, A.; Cortes-Funes, H. The role of rank-ligand inhibition in cancer: The story of denosumab. Oncologist 2011, 16, 136-145. [CrossRef] [PubMed]

69. Kang, Y.J.; Noh, J.E.; Lee, M.J.; Chae, W.S.; Lee, S.Y.; Kim, S.G. The effect of 4-hexylresorcinol on xenograft degradation in a rat calvarial defect model. Maxillofac. Plast. Reconstr. Surg. 2016, 38, 29. [CrossRef] [PubMed]

70. Kim, M.K.; Park, Y.T.; Kim, S.G.; Park, Y.W.; Lee, S.K.; Choi, W.S. The effect of a hydroxyapatite and 4-hexylresorcinol combination graft on bone regeneration in the rabbit calvarial defect model. Maxillofac. Plast. Reconstr. Surg. 2012, 34, 377-383.

71. Kim, S.G.; Hahn, B.D.; Park, D.S.; Lee, Y.C.; Choi, E.J.; Chae, W.S.; Baek, D.H.; Choi, J.Y. Aerosol deposition of hydroxyapatite and 4-hexylresorcinol coatings on titanium alloys for dental implants. J. Oral Maxillofac. Surg. 2011, 69, e354-e363. [CrossRef] [PubMed]

72. Seok, H.; Lee, S.W.; Kim, S.G.; Seo, D.H.; Kim, H.S.; Kweon, H.Y.; Jo, Y.Y.; Kang, T.Y.; Lee, M.J.; Chae, W.S. The effect of silk membrane plus 3\% 4-hexylresorcinol on guided bone regeneration in a rabbit calvarial defect model. Int. J. Ind. Entomol. 2013, 27, 209-217. [CrossRef]

73. Lee, S.W.; Um, I.C.; Kim, S.G.; Cha, M.S. Evaluation of bone formation and membrane degradation in guided bone regeneration using a 4-hexylresorcinol-incorporated silk fabric membrane. Maxillofac. Plast. Reconstr. Surg. 2015, 37, 32. [CrossRef] [PubMed]

74. Seok, H.; Jo, Y.Y.; Kweon, H.; Baek, D.H.; Kim, S.G. Comparative study on bone regeneration between silk mat incorporated 4-hexylresorcinol and collagen membrane. Int. J. Ind. Entomol. 2017, 34, 32-37. 
75. Anderson, J.M.; Rodriguez, A.; Chang, D.T. Foreign body reaction to biomaterials. Semin. Immunol. 2008, 20, 86-100. [CrossRef] [PubMed]

76. Kweon, H.; Kim, S.G.; Choi, J.Y. Inhibition of foreign body giant cell formation by 4-hexylresorcinol through suppression of diacylglycerol kinase delta gene expression. Biomaterials 2014, 35, 8576-8584. [CrossRef] [PubMed]

77. Chopra, I.; Roberts, M. Tetracycline antibiotics: Mode of action, applications, molecular biology, and epidemiology of bacterial resistance. Microbiol. Mol. Biol. Rev. 2001, 65, 232-260. [CrossRef] [PubMed]

78. Sanchez, A.R.; Rogers, R.S., 3rd; Sheridan, P.J. Tetracycline and other tetracycline-derivative staining of the teeth and oral cavity. Int. J. Dermatol. 2004, 43, 709-715. [CrossRef] [PubMed]

79. Golub, L.M.; McNamara, T.F.; Ryan, M.E.; Kohut, B.; Blieden, T.; Payonk, G.; Sipos, T.; Baron, H.J. Adjunctive treatment with subantimicrobial doses of doxycycline: Effects on gingival fluid collagenase activity and attachment loss in adult periodontitis. J. Clin. Periodontol. 2001, 28, 146-156. [CrossRef] [PubMed]

80. Gomes, P.S.; Fernandes, M.H. Effect of therapeutic levels of doxycycline and minocycline in the proliferation and differentiation of human bone marrow osteoblastic cells. Arch. Oral Biol. 2007, 52, 251-259. [CrossRef] [PubMed]

81. Seok, H.; Kim, S.G.; Kweon, H.; Jo, Y.Y.; Lee, K.G.; Kang, T.Y.; Chae, W.S.; Min, S.K.; Ahn, J.H.; Park, J.W. Comparison of different concentrations of tetracycline-loaded silk fibroin membranes on the guided bone regeneration in the rat calvarial defect model. Tissue Eng. Regen. Med. 2014, 11, 476-482. [CrossRef]

82. Lee, S.W.; Park, Y.T.; Kim, S.G.; Kweon, H.; Jo, Y.Y.; Lee, H.S. The effects of tetracycline-loaded silk fibroin membrane on guided bone regeneration in a rabbit calvarial defect model. Maxillofac. Plast. Reconstr. Surg. 2012, 34, 293-298.

83. Park, J.B. Effects of doxycycline, minocycline, and tetracycline on cell proliferation, differentiation, and protein expression in osteoprecursor cells. J. Craniofac. Surg. 2011, 22, 1839-1842. [CrossRef] [PubMed]

84. Zhang, K.H.; Yu, Q.Z.; Mo, X.M. Fabrication and intermolecular interactions of silk fibroin/hydroxybutyl chitosan blended nanofibers. Int. J. Mol. Sci. 2011, 12, 2187-2199. [CrossRef] [PubMed]

85. Cai, Z.X.; Mo, X.M.; Zhang, K.H.; Fan, L.P.; Yin, A.L.; He, C.L.; Wang, H.S. Fabrication of chitosan/silk fibroin composite nanofibers for wound-dressing applications. Int. J. Mol. Sci. 2010, 11, 3529-3539. [CrossRef] [PubMed]

86. Wu, Y.Y.; Jiao, Y.P.; Xiao, L.L.; Li, M.M.; Liu, H.W.; Li, S.H.; Liao, X.; Chen, Y.T.; Li, J.X.; Zhang, Y. Experimental study on effects of adipose-derived stem cell-seeded silk fibroin chitosan film on wound healing of a diabetic rat model. Ann. Plast. Surg. 2018, 80, 572-580. [CrossRef] [PubMed]

87. Lai, G.J.; Shalumon, K.; Chen, J.P. Response of human mesenchymal stem cells to intrafibrillar nanohydroxyapatite content and extrafibrillar nanohydroxyapatite in biomimetic chitosan/silk fibroin/nanohydroxyapatite nanofibrous membrane scaffolds. Int. J. Nanomed. 2015, 10, 567-584.

88. Li, D.W.; He, J.; He, F.L.; Liu, Y.L.; Liu, Y.Y.; Ye, Y.J.; Deng, X.; Yin, D.C. Silk fibroin/chitosan thin film promotes osteogenic and adipogenic differentiation of rat bone marrow-derived mesenchymal stem cells. J. Biomater. Appl. 2018, 32, 1164-1173. [CrossRef] [PubMed]

89. Andiappan, M.; Sundaramoorthy, S.; Panda, N.; Meiyazhaban, G.; Winfred, S.B.; Venkataraman, G.; Krishna, P. Electrospun eri silk fibroin scaffold coated with hydroxyapatite for bone tissue engineering applications. Prog. Biomater. 2013, 2, 6. [CrossRef] [PubMed]

90. Garagiola, U.; Grigolato, R.; Soldo, R.; Bacchini, M.; Bassi, G.; Roncucci, R.; De Nardi, S. Computer-aided design/computer-aided manufacturing of hydroxyapatite scaffolds for bone reconstruction in jawbone atrophy: A systematic review and case report. Maxillofac. Plast. Reconstr. Surg. 2016, 38, 2. [CrossRef] [PubMed]

91. Ito, Y.; Hasuda, H.; Kamitakahara, M.; Ohtsuki, C.; Tanihara, M.; Kang, I.K.; Kwon, O.H. A composite of hydroxyapatite with electrospun biodegradable nanofibers as a tissue engineering material. J. Biosci. Bioeng. 2005, 100, 43-49. [CrossRef] [PubMed]

92. Song, J.M.; Shin, S.H.; Kim, Y.D.; Lee, J.Y.; Baek, Y.J.; Yoon, S.Y.; Kim, H.S. Comparative study of chitosan/fibroin-hydroxyapatite and collagen membranes for guided bone regeneration in rat calvarial defects: Micro-computed tomography analysis. Int. J. Oral. Sci. 2014, 6, 87-93. [CrossRef] [PubMed]

93. Baek, Y.Y.; Kim, J.H.; Song, J.M.; Yoon, S.Y.; Kim, H.S.; Shin, S.H. Chitin-fibroin-hydroxyapatite membrane for guided bone regeneration: Micro-computed tomography evaluation in a rat model. Maxillofac. Plast. Reconstr. Surg. 2016, 38, 14. [CrossRef] [PubMed] 
94. Reddi, A.H. Regulation of cartilage and bone differentiation by bone morphogenetic proteins. Curr. Opin. Cell Biol. 1992, 4, 850-855. [CrossRef]

95. Kim, H.-S.; Park, J.C.; Yun, P.Y.; Kim, Y.K. Evaluation of bone healing using rhBMP-2 soaked hydroxyapatite in ridge augmentation: A prospective observational study. Maxillofac. Plast. Reconstr. Surg. 2017, $39,40$. [CrossRef] [PubMed]

96. Shalumon, K.; Lai, G.J.; Chen, C.H.; Chen, J.P. Modulation of bone-specific tissue regeneration by incorporating bone morphogenetic protein and controlling the shell thickness of silk fibroin/chitosan/nanohydroxyapatite core-shell nanofibrous membranes. ACS Appl. Mater. Interfaces 2015, 7, 21170-21181. [CrossRef] [PubMed]

97. Tong, S.; Xu, D.P.; Liu, Z.M.; Du, Y.; Wang, X.K. Synthesis of the new-type vascular endothelial growth factor-silk fibroin-chitosan three-dimensional scaffolds for bone tissue engineering and in vitro evaluation. J. Craniofac. Surg. 2016, 27, 509-515. [CrossRef] [PubMed]

98. Hwang, D.Y.; On, S.W.; Song, S.I. Bone regenerative effect of recombinant human bone morphogenetic protein-2 after cyst enucleation. Maxillofac. Plast. Reconstr. Surg. 2016, 38, 22. [CrossRef] [PubMed]

99. Akeson, A.L.; Greenberg, J.M.; Cameron, J.E.; Thompson, F.Y.; Brooks, S.K.; Wiginton, D.; Whitsett, J.A. Temporal and spatial regulation of VEGF-a controls vascular patterning in the embryonic lung. Dev. Biol. 2003, 264, 443-455. [CrossRef] [PubMed]

100. Katagiri, W.; Kawai, T.; Osugi, M.; Sugimura-Wakayama, Y.; Sakaguchi, K.; Kojima, T.; Kobayashi, T. Angiogenesis in newly regenerated bone by secretomes of human mesenchymal stem cells. Maxillofac. Plast. Reconstr. Surg. 2017, 39, 8. [CrossRef] [PubMed]

101. Zhang, Y.; Zhao, P.; Dong, Z.; Wang, D.; Guo, P.; Guo, X.; Song, Q.; Zhang, W.; Xia, Q. Comparative proteome analysis of multi-layer cocoon of the silkworm, bombyx mori. PLoS ONE 2015, 10, e0123403. [CrossRef] [PubMed]

102. Mondal, M. The silk proteins, sericin and fibroin in silkworm, bombyx mori linn.—A review. Casp. J. Environ. Sci. 2007, 5, 63-76.

103. Guo, X.; Dong, Z.; Zhang, Y.; Li, Y.; Liu, H.; Xia, Q.; Zhao, P. Proteins in the cocoon of silkworm inhibit the growth of beauveria bassiana. PLoS ONE 2016, 11, e0151764. [CrossRef] [PubMed]

104. Kim, W.J. Safety of infectious microorganism to silkworm for human and mammals. In Proceedings of the Conference for the Development of Sericulture Industry, Hallym University, Chuncheon, Korea, 23 May 2018. 